\title{
FLORISTIC DIVERSITY OF SECONDARY FOREST IN THE EASTERN AMAZON, STATE OF AMAPÁ
}

\author{
José Renan da Silva Guimarães ${ }^{1 *}$, Marcelo de Jesus Veiga Carim ${ }^{1,2}$, Salustiano Vilar da Costa Neto ${ }^{1}$, \\ Luciedi de Cássia Leôncio Tostes ${ }^{1,3}$ \\ ${ }^{1}$ Instituto de Pesquisas Científicas e Tecnológicas do Estado do Amapá, Macapá, Amapá, Brasil - *jrenansg@hotmail.com \\ ${ }^{2}$ Instituto Nacional de Pesquisas da Amazônia, Programa de Pós-Graduação em Botânica, Manaus, Amazonas, Brasil - \\ veigacarim@hotmail.com; \\ ${ }^{3}$ Instituto Nacional de Pesquisas da Amazônia, Programa de Pós-Graduação em Ciências de Florestas Tropicais, Manaus, Amazonas, Brasil - \\ luciedi.tostes@gmail.com; salucostaneto@gmail.com
}

Received for publication: 09/03/2015 - Accepted for publication: 07/07/2016

\begin{abstract}
The increasing importance of secondary forests all over the world alerts us to the urgent need to understand the biophysical and social underlying factors that affect its regeneration after the abandonment of agricultural practices and natural disturbances. In the state of Amapá, studies related to the structure of secondary forests are still scarce. Therefore, this article aims to characterize the floristic composition and structure in two stretches of secondary forest in the eastern Amazon, state of Amapá. For the floristic and phytosociological study of tree species, 10 plots of $10 \times 100 \mathrm{~m}$ (1.0 ha) were established: five plots in the community of São Francisco do Iratapuru and five plots in the community of Santo Antônio waterfall, totaling half a hectare $(0,5 \mathrm{ha})$ in each area. In all plots, subjects with diameter at breast height $(\mathrm{DBH}) \geq 5 \mathrm{~cm}$ were considered. In total, 1,183 subjects were sampled in the two stretches of forest. In stretch 01, 565 subjects belonging to 74 species, 55 genera and 33 families were recorded. In stretch 02, 618 subjects belonging to 26 species, 23 genera and 15 families were recorded. The Shannon diversity index $\left(\mathrm{H}^{\prime}\right)$, estimated for stretch 1, was 3.52; and for stretch 2 (2.23). The two studied stretches, despite being registered at the same age, showed significant difference in the species richness, which is the major factor for diversity differences, resulting in low similarity between the studied forests.
\end{abstract}

Keywords: Capoeira; structure; phytosociology.

\section{Resumo}

Diversidade florística em dois trechos de Floresta Secundária na Amazônia Oriental, estado do Amapá. O reconhecimento do papel das florestas secundárias na manutenção estrutural e funcional da biodiversidade em nível de paisagem e seu potencial ecológico passa pela intensificação dos estudos sobre sua dinâmica, conhecimento florístico e das condições atuais em que elas se encontram em diversas paisagens antropizadas. Este artigo objetivou caracterizar a diversidade florística em dois trechos de floresta secundária na Amazônia oriental, estado do Amapá. Para o estudo florístico e fitossociológico das espécies arbóreas, foram estabelecidas 10 parcelas de 10 x $100 \mathrm{~m}$ (1,0 ha): cinco na comunidade de São Francisco do Iratapuru e cinco na comunidade de Santo Antônio da Cachoeira, totalizando meio hectare (0,5 ha) em cada área. Em todas as parcelas foram mensurados indivíduos arbóreos com diâmetro a $1,30 \mathrm{~cm}$ do solo (DAP) $\geq 5 \mathrm{~cm}$. No total, foram amostrados 1.183 indivíduos nos dois trechos de floresta. No trecho 1 foram registrados 565 indivíduos, distribuídos em 74 espécies, 55 gêneros e 33 famílias. No trecho 2 foram registrados 618 indivíduos, distribuídos em 26 espécies, 23 gêneros e 15 famílias. O índice de diversidade de Shannon para o trecho 1 foi de $\mathrm{H}^{\prime}=3,52$ e para o trecho 2 foi de $\mathrm{H}^{\prime}=2,23$. Os dois trechos estudados, embora registrados com a mesma idade, apresentaram expressiva diferença na riqueza de espécies, sendo este o fator preponderante para diferenças de diversidade, culminando com a baixa similaridade entre as florestas estudadas.

Palavras-chave: Capoeira; estrutura; fitossociologia.

\section{INTRODUCTION}

Secondary forests are forests in natural regeneration after significant human and/or natural disturbances in the vegetation of the original forest, which may have occurred only once or progressively for long periods (CHOKKALINGAM; DE JONG, 2001).

The main examples of these formations in Amazon region are the fallow areas in the agricultural system of cut and burn and the vegetation formed after the abandonment of degraded pastures (PEREIRA; VIEIRA, 2001). In forests, where there occurs the secondary formation, the floristic composition modifies itself, turning 
the community into an increasingly complex and diverse one (SILVA et al., 2010). The misuse of these forestry resources has provided serious damage to these formations, seriously compromising its biodiversity (MARANGON et al., 2003).

In the Eastern Amazon, at least 100 species of plants from secondary forests are mentioned as useful for the rural population (PEREIRA; VIEIRA, 2001). From an environmental perspective, the growth of forests contributes for the absorption of carbon from the atmosphere, the reestablishment of hydrological functions of primary forests and the recovery of biodiversity. Studies on floristic composition are needed for that the mechanisms of transformation of the forest and its structure can be understood (SILVA et al., 2010). Such knowledge constitutes a basic tool for taking measures which aim the acceleration and guidance of the process of secondary succession, whether for preservation or commercial production.

Although many authors in Amazon region have addressed studies on secondary forests (VIEIRA; PROCTOR, 2007; PRATA et al., 2010; SALOMẪO et al., 2012), in the state of Amapá, academic works which demonstrate interest in better understanding these environments are poorly studied. Therefore, this work on secondary forest was motivated by the lack of information on this environment, mainly on arboreal-sized species. For that reason, this work aims to contribute with information about the composition, structure and diversity of secondary forests in the state of Amapá.

\section{MATERIAL AND METHODS}

\section{Area of study}

The area of study covers two stretches of secondary forest of approximately 40 years of abandonment, resulted from the vegetal suppression for familiar agriculture of local communities. They are located in the South-West of the state of Amapá, town of Laranjal do Jarí. The stretch 1 is located nearby the Community of São Francisco do Iratapuru, $00^{\circ} 33^{\prime} 46,75^{\prime \prime} \mathrm{S}$ and $52^{\circ} 34^{\prime} 52,54^{\prime \prime} \mathrm{W}$. The stretch 2 is located at $00^{\circ} 38^{\prime} 29,08^{\prime \prime} \mathrm{S}$ and $52^{\circ} 30^{\prime} 16,51^{\prime \prime} \mathrm{W}$, nearby the Community of Santo Antônio of waterfall. Those areas are under the domain of a Warm-Humid Tropical climate, characterized by temperatures that vary between $27^{\circ} \mathrm{C}$ to $35^{\circ} \mathrm{C}$ and a pluviometric index around $2.400 \mathrm{~mm}$ per year.

\section{Methodological procedure}

For the floristic and phytosociological study of arboreal species, there were established 10 parcels of $10 \times 100 \mathrm{~m}(1,0 \mathrm{ha})$, randomly allocated inside each area: five plots in the community of São Francisco do Iratapuru and five plots in the community of Santo Antônio waterfall, totaling half a hectare $(0,5$ ha) in each area. All individuals with diameter at breast height $(\mathrm{DBH}) \geq 5 \mathrm{~cm}$ were measured with the usage a of diameter tape. The height was estimated with a 6-meter-long stick, which contained a marking for each meter.

The species were recognized in the field by parabotanists; specimens of difficult identification were collected and identified by comparison to existent species in the Herbarium of Amapá (HAMAB), located at the Institute of Scientific and Technologic Research of the state of Amapá (IEPA). The adopted system for plant classification was APG III (APG, 2009).

\section{Estimated parameters}

The structure of this vegetation was evaluated using the following parameters: relative density (DR), relative frequency (FR), relative dominance (DoR) and Importance Value (VI) (MUELLER-DOMBOIS; ELLEMBERG, 1974). For diametrical structure analysis, the sample individuals were divided by classes, with ranges of $5 \mathrm{~m}$. The heights were also organized in crescent classes, with ranges of $4 \mathrm{~m}$, starting from the shortest height recorded of $2 \mathrm{~m}$, so that there is an estimation of the stratification degree of the vegetal formation which is being studied.

To evaluate the diversity in the communities, there were used Shannon-Wienner's index $\left(\mathrm{H}^{\prime}\right)$, which attributes higher value to rare species, and Simpson's index (D), which is not very influenced by rare species (MAGURRAN, 1988). The floristic similarity was calculated through Jaccard's index (ROSSATO et al., 2008). Jaccard's index considers the number of common species between two areas and the number of exclusive species in each area (MUELLER-DOMBOIS; ELLENBERG, 1974). Based on this index, it was elaborated a dendrogram based on the average of the group (UPGMA), in which the grouping is made from the arithmetic average of the elements, creating a dendrogram. In this dendrogram, the values of the ordinates express the similarities between the objects indicated in the abscissas (SNEATH; SOKAL, 1973). The data collection on similarity was made through programs in the package FITOPAC I (SHEPHERD, 1995). 


\section{RESULTS}

\section{Floristic aspects}

A total of 1.183 individuals were sampled in both forest stretches, and six species were common to both areas (Cupania scrobiculata Rich., Inga edulis Mart., Banara guianensis Aubl., Myrcia fallax (Rich.) DC, Cecropia membranacea Trecul e Gustavia augusta L.). In stretch 1,565 individuals were registered, distributed into 74 species, 55 genera and 33 families. In stretch 2, 618 individuals were registered, distributed into 26 species, 23 genera and 15 families. Analyzing the two stretches, the more representative families were: Fabaceae, with 318 individuals distributed into 11 species, emphasizing Inga thibaudiana DC as the most abundant species (68 individuals). The second family was Malvaceae (229), distributed into five species, emphasizing Apeiba tibourbou Aubl. (21) and the Salicaceae family, with 90 individuals distributed into six species. Figure 1 (A, B) shows the distribution of the number of individuals of the top 10 botanical families sampled in the two stretches.
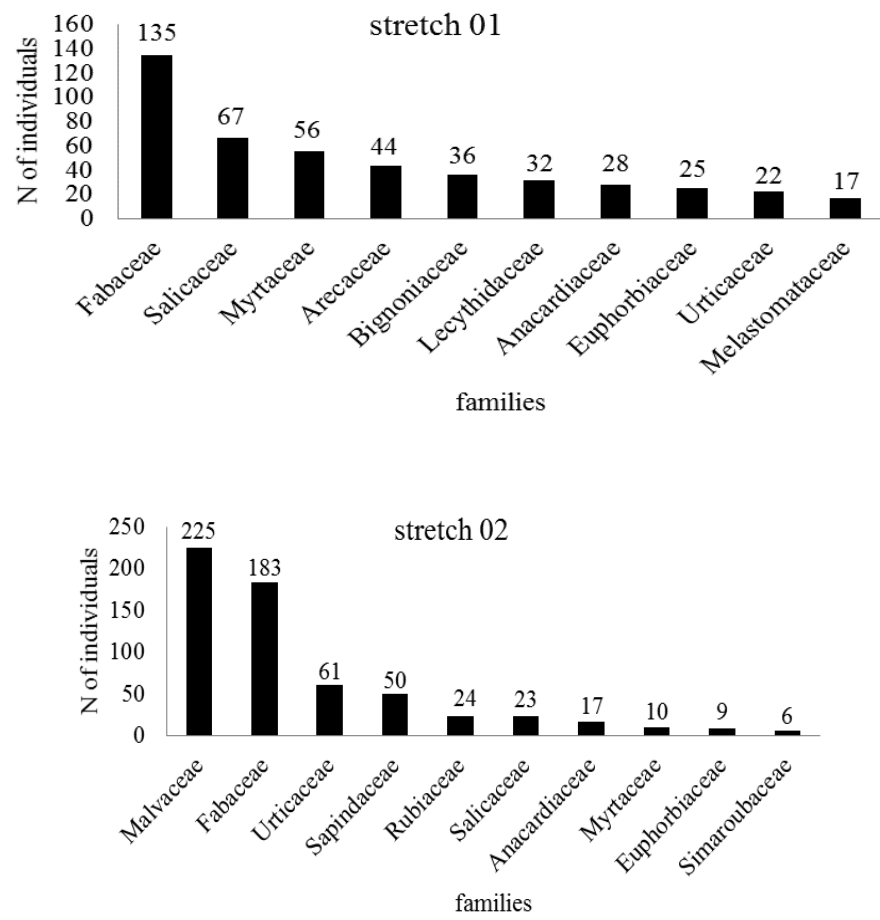

Figure 1. Distribution of the number of subjects from the 10 main botanical families sampled in secondary forest of the Eastern Amazon, state of Amapá, Brazil. Where: A = Stretch 1; B = Stretch 2.

Figura 1. Distribuição geral do número de indivíduos das 10 principais famílias botânicas amostradas em floresta secundária na Amazônia Oriental, estado do Amapá, Brasil. A = Trecho 1; B = Trecho 2.

The most abundant species in stretch 1 were Inga thibaudiana DC (68), Casearia arborea (rich.) Urb (50), Myrcia fallax (Rich.) DC (40), Jacaranda copaia (Aubl.) D. Don (36), Attalea maripa (Aubl.) Mart. (35), Tapirira guianensis Aubl. (28), Aparisthmium cordatum (A.Juss.) Baill. (25), Gustavia augusta L. (24), Cecropia membranacea Trecul (19) and Inga stipularis DC (17). In stretch 2, the most abundant species were Guazuma ulmifolia Lam. (202), Inga edulis Mart. (138), Cecropia membranacea Trecul (60), Inga brachystachys (Ducke) Ducke (34), Cupania scrobiculata Rich. (28), Apeiba tibourbou Aubl. (21), Cupania diphylla Vahl. (21), Calycophyllum spruceanum (Benth.) K. Schum (18), Spondias mombin L. (17) and Banara guianensis Aubl. (16). Analyzing the two areas together, the Guazuma ulmifolia species was enhanced for showing greater number of subjects (202) with nearly $17 \%$ of the total. This species was representative only in stretch 02 , followed by Inga edulis with 144 subjects, nearly 12\%, and Cecropia membranacea, with 79 subjects $(6,68 \%)$.

\section{Phytosociological aspects}

When analyzing the sampled species in regard to their ecological importance, the first ten with higher Importance Value Index (IVI), for stretch 01, were Attalea maripa (23,27), Inga thibaudiana (21,08), Jacaranda 
copaia (15,01), Casearia arborea (14,52), Tapirira guianensis (14,22), Myrcia fallax (13,30), Miconia affinis (12,33), Eriotheca longipedicellata $(9,95)$, Cecropia membranacea $(7,72)$ and Aparisthmium cordatum $(7,49)$. These species represent nearly $56 \%$ of the sampled subjects and $46 \%$ of the total IVI. In stretch 02 , the species were Guazuma ulmifolia (66,09), Inga edulis (60,86), Cecropia membranacea (31,46), Apeiba tibourbou (13,68), Inga brachystachys (11,67), Cupania scrobiculata (9,82), Spondias mombim $(8,37)$, Cupania diphylla $(8,11)$, Callycophyllum spruceanum $(7,66)$ and Banara guianensis $(7,30)$. These species represented nearly $90 \%$ of the sampled subjects and $75 \%$ of the total IVI, numbers that reveal the importance of these species in the two sampled areas.

Table 1. Phytosociological parameters of arboreal species, by decrescent order of importance value, sampled in both areas of secondary forest in Eastern Amazon, state of Amapá, Brazil. Number of individuals (N), relative density (DR), relative frequency (FR), relative dominance (DoR) and Importance Value (VI).

Tabela 1. Parâmetros fitossociológicos das espécies arbóreas, por ordem decrescente do valor de importância, amostradas nas duas áreas de floresta secundária na Amazônia oriental, estado do Amapá, Brasil. Número de indivíduos (N), Densidade relativa (DR), Frequência relativa (FR), Dominância relativa (DoR) e Valor de importância (VI).

\begin{tabular}{|c|c|c|c|c|c|c|}
\hline & Espécies & $\mathbf{N}$ & DR & FR & DoR & VI \\
\hline \multirow{10}{*}{ 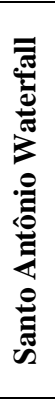 } & Guazuma ulmifolia & 202 & 32,7 & 3,85 & 29,6 & 22,03 \\
\hline & Inga edulis & 138 & 22,3 & 3,85 & 34,7 & 20,29 \\
\hline & Cecropia membranacea & 60 & 9,71 & 3,85 & 17,9 & 10,49 \\
\hline & Apeiba tibourbou & 21 & 3,4 & 3,85 & 6,44 & 4,56 \\
\hline & Inga brachystachys & 34 & 5,5 & 3,85 & 2,32 & 3,89 \\
\hline & Cupania scrobiculata & 28 & 4,53 & 3,85 & 1,44 & 3,27 \\
\hline & Spondias mombim & 17 & 2,75 & 3,85 & 1,78 & 2,79 \\
\hline & Cupania diphylla & 21 & 3,4 & 3,85 & 0,87 & 2,7 \\
\hline & Callycophyllum spruceanum & 18 & 2,91 & 3,85 & 0,9 & 2,55 \\
\hline & Banara guianensis & 16 & 2,59 & 3,85 & 0,86 & 2,43 \\
\hline \multirow{10}{*}{ 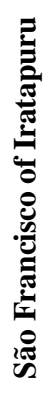 } & Attalea maripa & 35 & 6,18 & 1,35 & 15,73 & 7,76 \\
\hline & Inga thibaudiana & 68 & 12,01 & 1,35 & 7,71 & 7,03 \\
\hline & Jacaranda copaia & 36 & 6,36 & 1,35 & 7,29 & 5 \\
\hline & Casearia arborea & 50 & 8,83 & 1,35 & 4,33 & 4,84 \\
\hline & Tapirira guianensis & 28 & 4,95 & 1,35 & 7,92 & 4,74 \\
\hline & Myrcia fallax & 40 & 7,07 & 1,35 & 4,88 & 4,43 \\
\hline & Miconia affinis & 14 & 2,47 & 1,35 & 8,5 & 4,11 \\
\hline & Eriotheca longipedicellata & 2 & 0,35 & 1,35 & 8,24 & 3,32 \\
\hline & Cecropia membranacea & 19 & 3,36 & 1,35 & 3,02 & 2,57 \\
\hline & Aparisthmium cordatum & 25 & 4,42 & 1,35 & 1,72 & 2,5 \\
\hline
\end{tabular}

The stretch 1 showed an average height of $6 \mathrm{~m}$, with 75,92\% of its individuals grouped in the first two classes of height, varying from $2 \mathrm{~m}$ to $11 \mathrm{~m}$. The species Inga thibaudiana, Tapirira guianensis, Cecropia membranacea, Jacaranda copaia e Myrcia fallax were highlighted by the great height of its most emergent trees. The last one presented the biggest height $(18 \mathrm{~m})$.

In stretch 2, the distribution of individuals showed an average height of $10 \mathrm{~m}$, being $48,86 \%$ of them grouped in height classes winch vary from $7 \mathrm{~m}$ to $16 \mathrm{~m}$. The forest canopy was occupied by individuals which height varied from 17 to $28 \mathrm{~m}$, The specie Cupania diphylla was stressed as the highest in the studied environment (28 m) (Figure 2). 


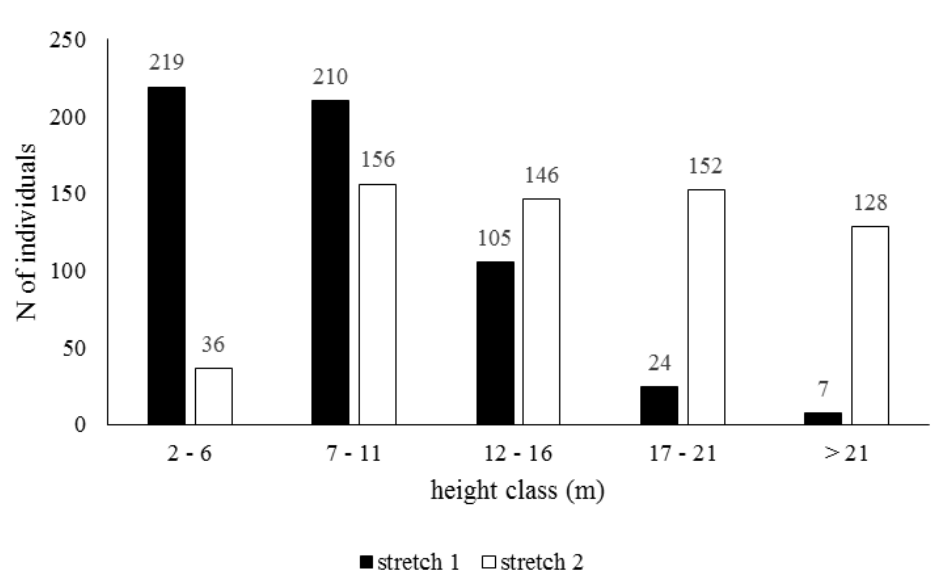

Figure 2. Distribution of individuals by heights classes $(\mathrm{m})$ of the arboreal species found in secondary forest in the eastern Amazon, state of Amapá, Brazil.

Figura 2. Distribuição dos indivíduos nas classes de alturas (m) das espécies arbóreas encontradas em floresta secundária na Amazônia oriental, estado do Amapá, Brasil.

The diametrical distribution of the studied stretches (Figure 3) showed the curve of diametrical distribution, which is similar to an inverted J, for both areas. The first class of diameter, including until $10 \mathrm{~cm}$ of DAP, presented individuals totalizing around 60\% (stretch 1) and 48\% (stretch 2) of the sample. The average diameter in stretch 1 was $10,85 \mathrm{~cm}$, with the biggest DAP belonging to the specie Eriotheca longipedicellata $(62.10 \mathrm{~cm})$. In stretch 2 , the average diameter was $12.04 \mathrm{~cm}$, the biggest DAP being presented by Apeiba tibourbou e Inga edulis (33,44 and 39,33 cm) respectively.

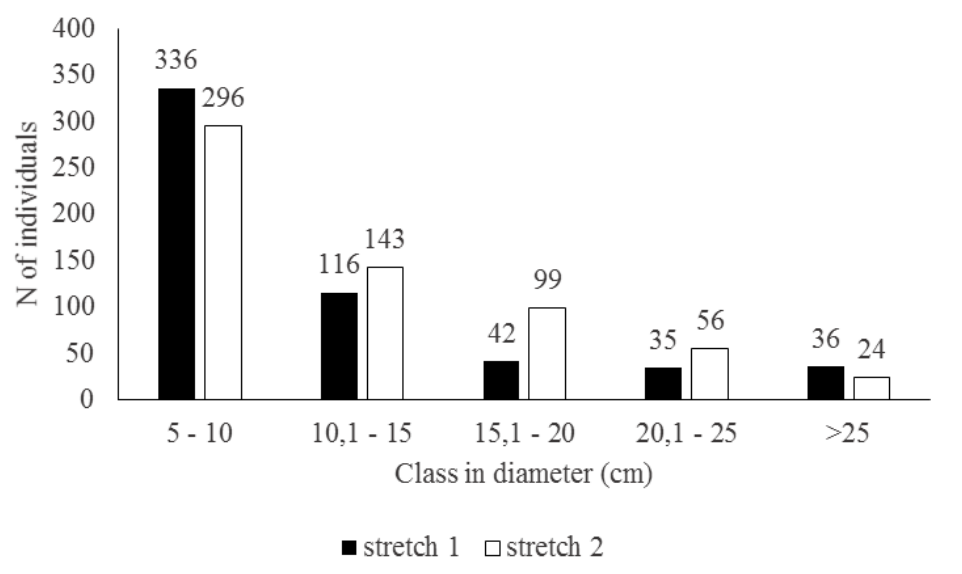

Figure 3. Distribution of subjects, by classes of $\mathrm{DBH}(\mathrm{cm})$, of arboreal species found in Secondary Forest in the eastern Amazon, state of Amapá, Brazil.

Figura 3. Distribuição dos indivíduos nas classes de DAP $(\mathrm{cm})$ das espécies arbóreas encontradas em floresta secundária na Amazônia oriental, estado do Amapá, Brasil.

\section{Floristic diversity}

Shannon's diversity index $\left(\mathrm{H}^{\prime}\right)$, estimated for stretch 1 , was 3,52 and for stretch 2 it was 2,23; in Simpson's index, it was 0,95 (stretch 1) and 0,82 (stretch 2). Despite presenting the largest number of species (74), stretch 1 shows lower density of individuals and a better distribution of these in the parcels. The evenness (J) for stretch 1 was 0,77 and 0,49 for stretch 2, demonstrating high uniformity in proportions individuals/species inside the vegetal community.

The dendrogram for both areas was obtained through Jaccard's similarity index (Figure 4). The dendrogram shows the formation of two distinct groups with a similarity cut around 0,10 in Jaccard's scale. The first group from 1 to 5 was established for the parcels allocated in stretch 1 and the second group (6 to 10), for 
stretch 2. The low similarity between the analyzed stretches reflects the marked difference in richness; only seven species were common for both stretches.

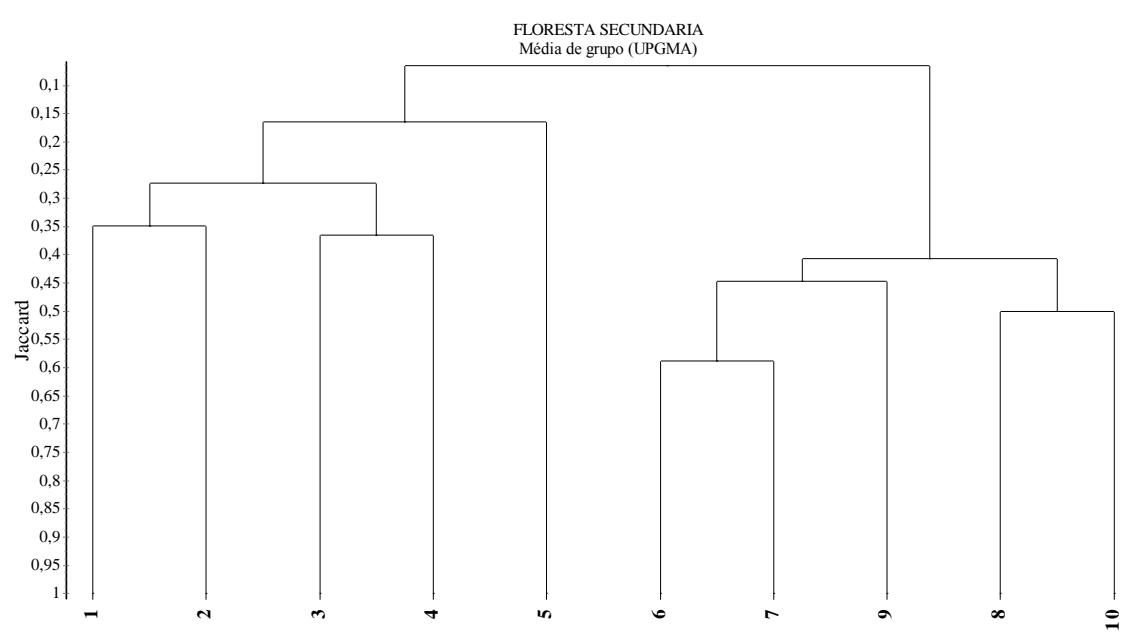

Figure 4. Group analysis dendogram, (UPGMA), using the Jaccard similarity index, for two stretches of Secondary Forest in the Eastern Amazon, state of Amapá.

Figura 4. Dendrograma de análise de agrupamento (UPGMA) utilizando o índice de similaridade de Jaccard, para os dois trechos de floresta secundária na Amazônia oriental, estado do Amapá.

Through analysis of the similarity degree between the parcels inside each stretch, it was observed a high similarity, with minimum differences between them. These results point that possibly the local conditions, inherent to each stretch, are acting in the composition of the species, with a cut of 0,6 between the parcels 6 and 7 .

\section{DISCUSSION}

The composition of the families is similar to other studies held on secondary forests in Amazon region (CARIM et al., 2007; RAYOL et al., 2008; RAYOL et al., 2011; ARAÚJO et al., 2012), being Fabaceae, Malvaceae, Myrtaceae, Salicaceae and Arecaceae the most important in the phytocoenosis.

The first ten families contributed with approximately $85 \%$ of abundance and approximately $49 \%$ of total richness. Among the families, $13 \%$ presented just one individual in the community, values that approach the ones in other studies held on secondary forest in Amazon region (CARIM et al., 2007; RAYOL et al., 2011), where there were found around $15 \%$ to $30 \%$ of species in the same frequency.

The Malvaceae family showed only four individuals in stretch 1 . However, it was the family which showed more individuals in stretch 2 (225 individuals), highlighting as the second most abundant family in the field of study, mainly propelled by the high number of individuals from species Guazuma ulmifolia Lam, a heliophytic specie, pioneer characteristic of secondary formations. Fabaceae and Malvaceae together correspond to $72 \%$ of the total abundance of these areas. These families lead on the proportion of hyper dominance in Amazon forest, and transit by all main types of forests, presenting a singular dominance pattern (TER STEEGE et al., 2013).

These botanical families do not share the same status regarding the richness of species and abundance, changing its sociological position according to its abundance and the size of the individuals. The abundance of individuals is not always proportional to the number of species, in which few species can be represented by big populations or a single specie can be very abundant in the community (KUNZ et al., 2008). In this academic work, Malvaceae e Myrtaceae are typical examples of this pattern, in which the status is defined by the number of individuals and richness of species, respectively.

In the other extreme, approximately $2 \%$ of the species were represented by only one individual. The stretch 1 concentrated the majority of these individuals (16), and stretch 2 held four individuals. These species are considered rare only in the numerical concept for a determined area in a determined moment, and not necessarily from biological perspective.

When analyzing the sampled species regarding its ecological significance (table 1), other studies point these same species as the most important in the communities studied, which clearly defines the sovereignty of these species in secondary forests (CARIM et al., 2007). The sociological position allows the understanding of how these individuals behave in the community, as well as its phytosociologycal importance. The presence of 
the species Vismia spp. and Cecropia spp., are typical from environments in formation; they are pioneers, sometimes they persist in the environment, even reaching an advanced stage of succession. They are typical from environments with great human impact, such as old pastures or annual farming.

The individuals were estimated with a height lower than $20 \mathrm{~m}$ in stretch 1, which allows the assumption of a balance in succession dynamics. Many species which integrate lower stages remain in the late stages of succession (PEREIRA et al., 2011). Anyhow, in this stretch, the response of organisms to the environmental conditions can satisfactorily affect the height of individuals. Ribeiro et al. (2013), establishes effective relation of physical and chemical parameters of the soil on the structural characteristics of forests in formation, an analysis which is not proposed by this study.

Through the analysis of the vertical structure, it is possible to have an idea of the importance of some species for a forestry stretch, considering its participation in vertical strata (POLISEL, 2013) Those species which have a greater number of representative individuals in each of these strata will certainly show more ecological importance in the population studied (MARANGON et al., 2003).

Regarding the data on diametrical distribution of arboreal individuals, the largest concentration occurred in the first class of diameter (Figure 3), around 60\% (stretch 1) and 48\% (stretch 2) of the total analyzed. Secondary formations in early stages of succession present similar characteristics to the one presented in this work (CARIM et al., 2007; RAYOL et al., 2011). For other classes, there was a sharp decrease of individuals. Most or almost the total of the inventory of tree and shrub communities of secondary forests presents a diametrical distribution following the model inverted "J" (MACHADO et al., 2004).

Such occurrence in the diametrical structure of the forest indicates a tendency for balanced distribution, due to the regeneration capacity of vegetable species, however, the great amount of individuals in smaller diameter classes may point that the disturbance regime is relatively intense and continuous (MACHADO et al., 2004).

The large amount of small and thin individuals may indicate the occurrence of several disturbances in the past, therefore, Martins (1991) warned that the highest density of smaller individuals does not indicate an absence of regeneration problems, which should be carefully considered, demonstrating the need of a more detailed analysis, in a specific level and with a larger group of species, so that it can be taken more reliable interpretations of the diametrical distributions.

Regarding the diversity presented, stretch 1 approached the results obtained by Rayol et al. (2011), who registered $(3,62)$ in a forest of about 30 years old and by Carim et al. (2007) in secondary forests in the municipality of Bragança, PA, being $(3,90)$ for the 25 -year-old forest and $(3,07)$ for the 15 -year-old forest.

What denotes such a difference between the richness of species in these environments? What factors acted to establish these differences? These questions will need more advanced studies on hydrogeomorphological and/or bioecological aspects of the species. Anyway, there are bioecological mechanisms acting together and differently in the environments. Understanding these mechanisms, we can advance in the understanding of diversity variation and richness in these environments. Forests in succession already allow us to establish relations between the bioecology of species, pointing elements which act in persistence for the formation of primary forests, such as: dispersion, predation, soil, temperature, water, luminosity and hydric regime (JONES et al., 2006; TER STEEGE et al., 2006). Besides these elements, the successional stage and the disturbance history of the forests may influence the number of species found in the community (TABARELLI; MANTOVANI, 1999).

It is clear that throughout its evolution, the forest tends to increase its richness and diversity, the succesional process imposes necessary conditions for the establishment of new species, culminating with the required balance for the maintenance of the high diversity of tropical forests. Studies held by Prata et al. (2010) also indicate an increase in the diversity of successional forests.

The low similarity between the analyzed stretches reflect the high difference of richness, with only seven species common for both environments. For Ribas et al. (2003) the age of the chronosequences connected to the abiotic attributes are fundamental for the low similarity. Therefore, both environments may have undergone by processes of history of soil occupation, considering their same age of exploitation. The similarity value between the environments is considered very low, once the Jaccard scale varies from the total nonsimilarity " 0 " (zero) and the maximum similarity "1" (one).

\section{CONCLUSIONS}

- Both stretches studied, registered with the same exploitation age, showed differences regarding the richness of its species, resulting in a low similarity between the studied stretches. The geographic distance between these areas and the different use and occupation of the soil may be influencing the differences of richness and non-similarity between the environments. Normally, these environments can be classified as a transition 
for the final succession pattern, with a large size in height and diameter. Only seven species were common for both environments, which differed a little as it comes to vertical and horizontal structure.

- The differences registered in the composition of species and diversity suggest the species are giving a different response for environmental effects. For that reason, more advanced studies are needed so that these relations can be understood.

\section{REFERENCES}

APG III. An update of the Angiosperm Phylogeny Group classification for the orders and families of flowering plants: APG III. Botanical Journal of the Linnean Society, London, n. 161, i. 2, p. 105-121, 2009.

ARAÚJO, G. C.; OLIVEIRA JUNIOR, R. C.; OLIVEIRA, F. A.; GAMA, J. R. V.; GONÇALVES, D. C. M.; ALMEIDA L. S. Comparação entre Floresta Primária e Secundária com Ocorrência de Attalea maripa (Aubl.) Mart.: Estudo de Caso na Amazônia Oriental. Floresta e Ambiente, v. 19, n. 3, p. 325-335, 2012.

CARIM, S.; SCHWARTZ, G.; SILVA, M. F. F. Riqueza de espécies, estrutura e composição florística de uma floresta secundária de 40 anos no leste da Amazônia1. Acta Botânica Brasílica, v. 21, n. 2, p. 293-308, 2007.

CHOKKALINGAM, U.; DE JONG, W. Secondary forest: a working definition and typology. International Forestry Review, v. 3, n. 1, p. 19-29, 2001.

JONES, M. M.; TUOMISTO, H.; CLARK, D. B.; OLIVAS, P. Effects of mesoscale environmental and dispersal limitation on floristic variation in rain forest ferns. Journal of Ecology, v. 94, p. 181-195, 2006.

KUNZ, S. H.; IVANAUSKAS, N. M.; MARTINS, S. V.; SILVA, E.; STEFANELlO, D. Aspectos florísticos e fitossociológicos de um trecho de Floresta Estacional Perenifólia na Fazenda Trairão, Bacia do rio das Pacas, Querência, MT. Acta Amazônica, v. 38, p. 245-254, 2008.

MACHADO, E. L. M.; OLIVEIRA FILHO, A. T.; CARVALHO, W. A. C.; SOUZA, J. S.; BORÉM, R. A. T.; BOTEZELLI, L. Análise comparativa da estrutura e flora do compartimento arbóreo-arbustivo de um remanescente florestal na fazenda Beira Lago, Lavras, MG. Revista Árvore, v. 28, n. 4, p. 499-516, 2004.

MARANGON, L. C.; SOARES, J. J.; FELICIANO, A. L. P. Florística arbórea da Mata da Pedreira, município de Viçosa, Minas Gerais. Minas Gerais. Revista Árvore. v. 27, n. 2, p. 207-215, 2003.

MARTINS, F. R. Estrutura de uma floresta mesófila. Campinas: UNICAMP, 1991. 245 p.

MUELlER-DOMBOIS, D.; ElLENBERG. H. Aims and Methods of Vegetation Ecology. Wiley, New York. 547 p. 1974.

PEREIRA, C. A.; VIEIRA, I. C. G. A importância das florestas secundárias e os impactos de sua substituição por plantios mecanizados de grãos na Amazônia. INCI, v. 26, p. 337-341, 2001.

PEREIRA, L. A.; SOBRINHO, F. A. P.; COSTA NETO, S. V. Florística e estrutura de uma mata de terra firme na Reserva de Desenvolvimento Sustentável Rio Iratapuru, Amapá, Amazônia Oriental, Brasil. Floresta (Online) (Curitiba), v. 41, p. 113-122, 2011.

POLISEL, R. T. Levantamento fitossociológico e caráter sucessional de um trecho de Floresta Secundária Ciliar em Juquitiba, SP, Brasil. Revista Árvore, Viçosa-MG, v. 37, n. 5, p. 789-799, 2013.

PRATA, S. S.; MIRANDA, I. S.; ALVES, S. A. O.; FARIAS, F. C.; JARDIM, F. C. S. Gradiente florístico das florestas secundárias do nordeste paraense. Acta Amazônica, v. 40, n. 3, p. 523-533, 2010.

RAYOL, B. P.; ALVINO-RAYOL, F. O.; SILVA, M. F. F. Estrutura e composição florística da regeneração natural de duas florestas secundárias em Capitão Poço, Pará, Brasil Amazônia: Ciência \& Desenvolvimento, Belém, v. 4, n. 7, 2008.

Similaridade florística entre o estrato arbóreo e a regeneração natural de uma floresta secundária, no município de Bragança, nordeste do estado do Pará, Brasil. Revista Brasileira de Agroecologia. v. 6, p. 107$114,2011$.

RIBEIRO, T. M.; IVANAUSKAS, N. M.; MARTINS, S. V.; POLISEL, R. T.; SANTOS, R. L. R. Fitossociologia de uma Floresta Secundária com Araucaria angustifolia (Bertol.) O. Kuntze na Estação Ecológica de Bananal, Bananal, SP. Floresta e Ambiente, v. 20, p. 159-172, 2013. 
ROSSATO, D. R.; TONIATO, M. T. Z.; DURIGAN, G. Flora fanerogâmica não arbórea do cerrado na Estação Ecológica de Assis, estado de São Paulo. Revista Brasileira de Botânica, v. 31, p. 409-424, 2008.

SALOMÃO, R. P.; VIEIRA, I. C. G.; BRIENZA JUNIOR, S.; AMARAL, D. D.; SANTANA, A. C. Sistema Capoeira Classe: uma proposta de sistema de classificação de estágios sucessionais de florestas secundárias para o estado do Pará. Boletim Museu Paraense. Emílio Goeldi. Cienc. Nat., Belém, v. 7, n. 3, p. 297-317, 2012.

SHEPHERD, G. J. FITOPAC 1: manual do usuário. Campinas, Unicamp. 1995.

SILVA, W. C.; MARANGON, L. C.; FERREIRA, R. L. C.; FELICIANO, A. L. P.; APARICIO, P. S.; COSTA JUNIOR, R. F. Estrutura horizontal e vertical do componente arbóreo em fase de regeneração natural na Mata Santa Luzia, no município de Catende, PE. Revista Árvore, v. 34, p. 863-869, 2010.

SNEATH, P. H. A.; SOKAL, R. R. Numerical Taxonomy - The principles and ractice of numerical classification. W. H. Freeman and company. San Francisco, U.S.A, 1973. 573 p.

TABARELLI, M.; MANTOVANI, W. A regeneração de uma floresta tropical montana após corte e queima (São Paulo - Brasil). Revista Brasileira de Biologia, v. 59, n. 2, p. 239-251, 1999.

TER STEEGE, H. et al. Science 342, 1243092 (2013). DOI: 10.1126/science. 1243092.

TER STEEGE, H.; PITMAN, N. C. A.; PHILlIPS, O. L.; CHAVE, J.; SABATIER, D.; DUQUE, A.; MOLINO, J. F.; PRÉVOST, M. F.; SPICHIGER, R.; CASTELLANOS, H. Continental-scale patterns of canopy tree composition and function across Amazonia. Nature, v. 443, p. 444-447, 2006.

VIEIRA, I. C. G.; J. PROCTOR. Mechanisms of plant regeneration during succession after shifting cultivation in eastern Amazonia. Plant Ecology, v. 192, p. 303-315, 2007. 